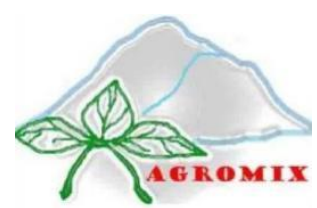

\title{
AGROMIX
}

Jurnal IImiah Fakultas Pertanian, Universitas Yudharta Pasuruan pISSN (Print): 2085-241X; elSSN (Online): 2599-3003

Website: https://jurnal.yudharta.ac.id/v2/index.php/agromix

\section{Evaluasi formulasi dan pembuatan complete feed bahan pakan lokal daun kopi di peternak sapi potong Pasuruan Jawa Timur}

\section{Evaluation of formulation and preparation of complete feed local food ingredients from coffee leaves at beef cattle breeders Pasuruan, East Java}

\author{
Yudi Rustandi ${ }^{1 *}$, Ismuladi ${ }^{1}$, Mirna Silfiani ${ }^{1}$ \\ ${ }^{1}$ Program Studi Penyuluhan Peternakan dan Kesejahteraan Hewan, Politeknik Pembangunan Pertanian, Malang, Jawa Timur \\ *Email korespondesi: yudinamiabdi0864@gmail.com
}

\section{Article History}

Received : November 01, 2020

Accepted : March 02, 2021

Published : March 10, 2021

\section{Keyword}

Evaluation; complete feed; beef cattle; local ingredients; coffee leaves

\section{ABSTRACT}

This study aims to evaluate the preparation of feed formulations and the manufacture of complete feed fermentation based on local ingredients of coffee leaves. This research has three stages: preparation of complete feed formulations using trial and error methods using Microsoft Excel, trials of making complete feeds, and evaluating complete feed products. Evaluation is carried out on four aspects, namely; The nutritional composition of the complete feed has been fulfilled compared to the SNI for Beef Cattle Feed, which analyzed through a bar chart, the complete feed characteristic organoleptic test for texture, color, aroma, and presence of mushrooms through 24 respondents, palatability test carried out on six beef cattle belonging to farmer group members, and the economic aspect of the manufacturing cost component. The evaluation results show; the formulation and manufacture of complete feeds are by the SNI for Beef Cattle Feed. The characteristics of the compiled complete feeds are solid texture, not thick, not slimy and brittle, yellowish-green with sour aroma, and no fungus found are the characteristics of successful fermentation, preference test that all cows like complete feeds, and the results of the economic evaluation that each kilogram of complete feed costs Rp. 1,629.34, which is lower than the price of rice straw per kilogram.

\section{Riwayat Artikel \\ Dikirim : 1 Nopember 2020 \\ Disetujui : 2 Mare 2021 \\ Dipublis : 10 Maret 2021}

\section{Kata Kunci}

Evaluasi, complete feed, sapi potong, bahan lokal, daun kopi

\section{ABSTRAK}

Penelitian ini bertujuan mengevaluasi penyusunan formulasi pakan dan pembuatan pakan fermentasi complete feed berbasis bahan lokal daun kopi. Terdapat tiga tahapan dalam penelitian ini, yaitu; penyusunan formulasi complete feed dengan metode trial and error menggunakan Microsoft Excel, uji coba pembuatan complete feed, dan evaluasi produk complete feed. Evaluasi dilakukan terhadap empat aspek, yaitu; kondisi komposisi nutrisi complete feed sudah terpenuhi dibandingkan dengan SNI Pakan Sapi Potong yang di analisis melalui diagram batang (bar chart), uji organoleptik karakteristik complete feed untuk tekstur, warna, aroma, dan keberadaan jamur melalui 24 orang responden, uji palatabilitas dilakukan kepada enam ekor sapi potong milik anggota kelompok tani, dan aspek ekonomi dari komponen biaya pembuatan. Hasil evaluasi menunjukkan; penyusunan formulasi dan pembuatan complete feed sudah sesuai SNI Pakan Sapi Potong, karakteristik complete feed yang telah dikompilasi adalah tekstur padat, tidak kental, tidak berlendir dan rapuh, hijau kekuningan dengan aroma asam dan tidak ditemukan adanya jamur merupakan ciri-ciri fermentasi berhasil, tes preferensi bahwa semua sapi menyukai complete feed, dan hasil evaluasi ekonomi bahwa setiap kilogram complete feed menghabiskan biaya Rp. 1.629,34, lebih rendah dari harga jerami padi per kilogram.

Sitasi: Rustandi, Y., Ismuladi, I., \& Silfiani, M. (2021). Evaluasi formulasi dan pembuatan complete feed bahan pakan lokal daun kopi di peternak sapi potong Pasuruan Jawa Timur. Agromix, 12(1), 62-67. https://doi.org/10.35891/agx.v12i1.2337

\section{PENDAHULUAN}

Budi daya sapi potong merupakan proses produksi dalam kegiatan agribisnis di bidang peternakan yang memiliki peluang terbuka, menjanjikan dan menguntungkan. Hal ini dikarenakan kebutuhan konsumsi daging sapi perkapita di Indonesia dari tahun ke tahun semakin meningkat yakni dari 2,2 kg/kapita/tahun pad a tahun 2015 menjadi 2,6 $\mathrm{kg} / \mathrm{kapita} /$ tahun pada tahun 2016, dalam kurun waktu yang sama penyediaan daging sapi lokal rata-rata hanya mampu memenuhi 65,24\% (Dinas Peternakan Prov Jawa Timur, 2018). Usaha sapi potong ini sangat potensial dikembangkan dikarenakan berbagai faktor yaitu: 1) pasar penyerap daging pada setiap harinya sangat besar mulai 
dari rumah tangga, rumah makan skala kecil hingga restoran bintang lima, dan 2) harga daging melonjak atau naik saat hari besar seperti hari raya (Rahmat \& Harianto, 2012).

Pakan adalah aspek paling penting untuk meraih kesuksesan dalam usaha beternak ruminansia, hal ini dikarenakan pakan menyerap 60-70\% biaya produksi (Angkasa, 2017). Produktivitas ternak pada masa pertumbuhan dan kemampuan produksinya dipengaruhi oleh faktor genetik $30 \%$ dan lingkungan (pakan, pemeliharaan, kesehatan dan iklim) 70\% dengan pakan memegang peran paling besar yaitu sebanyak 60\%. Besarnya pengaruh pemberian pakan ini membuktikan bahwa produksi ternak yang tinggi tidak bisa tercapai tanpa pemberian pakan yang memenuhi persyaratan kualitas dan kuantitas (Rianto \& Purbowati, 2009).

Pakan yang berkualitas dan terpenuhi kuantitasnya secara kontinyu sangat diharapkan oleh para peternak. Akan tetapi pada musim kemarau peternak sangat terbebani oleh rendahnya produksi hijauan pakan ternak (Elly dkk., 2013). Saat musim kemarau di Kabupaten Pasuruan, peternak memberikan pakan berupa jerami padi yang dibeli dari petani dengan harga Rp. 5.000. Menurut peternak harga tersebut dinilai mahal dikarenakan berat setiap ikat jerami sekitar 2-3 kg. Dalam rangka mengatasi beban pengeluaran peternak sapi dari aspek pakan diperlukan inovasi pengolahan pakan berupa pakan complete feed berbasis bahan pakan lokal yang tersedia secara terus menerus, berkualitas dan harganya terjangkau (Baba dkk., 2011). Bahan pakan lokal yang terdapat di daerah dataran tinggi Kab Pasuruan bisa didapatkan dari daun kopi yang jatuh sendiri maupun hasil kegiatan pemangkasan tanaman kopi.

Badan Pusat Statistik [BPS] Jawa Timur (2019), menyatakan bahwa Kab Pasuruan merupakan salah satu penghasil kopi di provinsi Jawa Timur di mana produksinya mencapai 3.102 ton pada tahun 2015. Untuk mendapatkan produksi yang tinggi, perlakuan pada tanaman kopi harus menerapkan pemeliharaan yang intensif. Salah satu pemeliharaan tanaman kopi yang harus dilakukan adalah pemangkasan batang tanaman kopi. Pada umumnya hasil dari pemangkasan batang tanaman kopi juga daunnya tersebut dibuang begitu saja. Padahal daun kopi ini dapat dimanfaatkan sebagai pakan alternatif sapi potong. Daun kopi dapat digunakan sebagai pakan alternatif sapi potong dan diberikan saat produksi hijauan berkurang khususnya pada musim kemarau (Dewi dkk., 2017). Kualitas dan kandungan nutrisi daun kopi tidak jauh berbeda dari daun gamal, yaitu memiliki kandungan Protein Kasar (PK) 23\% (Astuti \& Harta 2015). Manfaat penggunaan daun kopi sebagai pakan ternak yaitu efisiensi tenaga kerja, pakan alternatif saat musim kemarau dan efisiensi limbah perkebunan (Kuswandi, 2011).

Teknologi pengolahan pakan yang direkomendasikan untuk mengolah rumput gajah dan daun kopi adalah fermentasi complete feed berbasis bahan pakan lokal. Complete feed adalah metode pemberian pakan dengan mencampurkan hijauan dan konsentrat secara homogen yang bertujuan untuk meningkatkan nilai nutrisi pakan, palatabilitas serta mencegah ternak menseleksi pakan (Thiasari \& Setiyawan, 2016). Untuk mendapatkan produk akhir complete feed yang baik terlebih dahulu perlu ditetapkan formulasinya. Tujuan perhitungan formulasi tersebut adalah agar terpenuhinya standar mutu pakan dengan biaya pakan yang terjangkau oleh peternak (Agustono dkk., 2017). Penelitian ini bertujuan mengevaluasi penyusunan formulasi pakan dan pembuatan pakan fermentasi complete feed berbasis bahan lokal daun kopi.

\section{METODE}

Penentuan formulasi complete feed untuk sapi potong berdasarkan bahan pakan lokal yaitu rumput gajah, daun kopi, dedak padi dan pollard. Pembuatan formulasi ini menggunakan perhitungan trial or error (Hidayat \& Mukhlash, 2015). Metode trial and error merupakan metode penyusunan ransum yang dilakukan dengan menggunakan bantuan program Microsoft Excel dengan prinsip melakukan coba-coba guna mendapatkan nilai nutrisi dari ransum yang sesuai dengan kebutuhan atau keinginan yang telah ditentukan sebelumnya (Zakariah, 2016). Analisis proksimat complete feed untuk sapi potong dilakukan di Loka Penelitian Sapi Potong, Grati Pasuruan. Jenis proksimat yang dilakukan adalah Kadar Air, Bahan Kering (BK), Lemak Kasar (LK), Serat Kasar (SK), Kadar Abu dan BETN.

Uji organoleptik dilakukan untuk mengevaluasi hasil pembuatan fermentasi complete feed berdasarkan karakteristik yang terdiri dari aroma, warna, tekstur dan kontaminasi jamur (Septian dkk., 2011). Uji organoleptik dilaksanakan di Laboratorium Nutrisi dan Pakan Ternak Kampus Politeknik Pembangunan Pertanian Malang dengan dasar panelis tidak terlatih berjumlah 24 orang dengan syarat seimbang antara laki-laki dan perempuan. Uji organoleptik menggunakan kuesioner tertutup dengan 4 aspek yaitu tekstur, warna, aroma dan keberadaan jamur. Uji palatabilitas atau kesukaan ternak terhadap pakan yang diberikan (Christi dkk., 2018), dilakukan pada 6 (enam) ternak di peternak sapi potong anggota kelompok tani. Sedangkan untuk evaluasi aspek ekonomi dengan mengetahui besarnya biaya produksi complete feed per satuan kilogram. 


\section{HASIL DAN PEMBAHASAN}

\section{Menghitung formulasi complete feed sapi potong}

Penentuan formulasi complete feed untuk sapi potong berdasarkan bahan pakan lokal yaitu rumput gajah, daun kopi, dedak padi dan pollard. Pembuatan formulasi ini menggunakan perhitungan trial or error. Metode trial and error merupakan metode penyusunan ransum yang dilakukan dengan menggunakan bantuan program Microsoft Excel dengan prinsip melakukan coba-coba guna mendapatkan nilai nutrient dari ransum yang sesuai dengan kebutuhan atau keinginan yang telah ditentukan sebelumnya (Zakariah, 2016). Adapun formulasi complete feed untuk sapi potong disajikan pada Tabel 1.

Tabel 1. Formulasi coplete feed sapi potong bahan lokal daun kopi

\begin{tabular}{|c|c|c|c|c|c|c|c|}
\hline \multirow{2}{*}{ No } & \multirow{2}{*}{ Bahan Pakan } & \multirow{2}{*}{$\begin{array}{c}\text { Proporsi } \\
\%\end{array}$} & \multicolumn{5}{|c|}{ Kandungan Nutrisi } \\
\hline & & & $\mathrm{BK}$ & PK & LK & SK & TDN \\
\hline 1. & Rumput gajah & 40 & 35,96 & 3,68 & 0,92 & 13,28 & 18,4 \\
\hline 2. & Daun kopi & 20 & 6,21 & 3,41 & 0,65 & 5,28 & 0 \\
\hline 3. & Dedak padi & 10 & 9,13 & 0,99 & 0,23 & 1,85 & 5,55 \\
\hline 4. & Pollard & 28 & 25,33 & 4,88 & 0,97 & 1,15 & 21,39 \\
\hline 5. & Molases/tetes tebu & 2 & 0,60 & 0,17 & 0 & 0 & 1,26 \\
\hline & Total & 100 & 77,23 & 13,13 & 2,77 & 21,56 & 46,60 \\
\hline
\end{tabular}

Sumber: Pengolahan data primer, 2019.

Pada Tabel 1 menunjukkan formulasi complete feed sapi potong terdiri dari rumput gajah 40\%, daun kopi $20 \%$, dedak padi $10 \%$, pollard $28 \%$ dan molases atau tetes tebu $2 \%$. Penyusunan formulasi complete feed memakai pedoman SNI Mutu Pakan Sapi Potong yang diatur pada Permentan Nomor 46 tahun 2015.

\section{Pembuatan complete feed sapi potong bahan pakan lokal daun kopi}

\section{Alat dan bahan}

Peralatan yang dipakai dalam pembuatan complete feed, yaitu: sabit, parang, timbangan, plastik/silo/ember (tempat penyimpanan), terpal, alat penyiram, sendok, ember, dan gelas ukur. Bahan pembuatan complete feed terdiri dari; $40 \%$ rumput gajah, $28 \%$ pollard, $20 \%$ daun kopi daun kopi, $10 \%$ dedak padi, dan $2 \%$ molases atau tetes tebu.

\section{Cara pembuatan}

Pembuatan complete feed sapi potong ini sebanyak $25 \mathrm{~kg}$ yang akan digunakan untuk uji organoleptik, palatabilitas dan uji proksimat. Adapun cara pembuatan complete feed untuk sapi potong sebagai berikut:

1. Menyiapkan alat yang meliputi parang, sabit, timbangan, plastik/silo/ember (tempat penyimpanan), terpal, alat penyiram, sendok, gelas ukur dan ember.

2. Menyiapkan bahan yang meliputi hijauan pakan ternak (rumput gajah), limbah pertanian/industri/perkebunan (daun kopi), dedak padi dan pollard molasses (tetes tebu) dan EM4 dan disesuaikan dengan formulasi yang telah disusun.

3. Memotong rumput gajah menggunakan mesin chopper atau pencacahan rumput gajah secara manual menggunakan parang.

4. Mencacah daun kopi menggunakan sabit atau pisau.

5. Melayukan rumput gajah dan daun kopi selama 2-3 jam.

6. Menaburkan hijauan pakan ternak (rumput gajah) di atas terpal secara merata, kemudian daun kopi, pollard dan terakhir dedak padi.

7. Membuat larutan dari Air sebanyak 3\% dari total bahan, EM4 $1 \%$ dari total air dan molases $2 \%$ dari total bahan.

8. Menyiramkan larutan di atas hijauan dan konsentrat hingga rata.

9. Tutup rapat bak menggunakan plastik hingga tidak ada udara yang masuk. Meletakkan pemberat di atasnya untuk memastikan udara tidak dapat masuk. Proses penyimpanan dilakukan selama 7 hari.

10. Sebelum diberikan kepada ternak sebaiknya diangin-anginkan terlebih dahulu.

\section{Keragaan komposisi nutrisi antara formulasi complete feed sapi potong bahan pakan lokal daun kopi dengan SNI} mutu pakan sapi potong

Analisis proksimat complete feed sapi potong dilakukan di Loka Penelitian Sapi Potong, Grati Pasuruan. Jenis proksimat yang dilakukan adalah Kadar Air, Bahan Kering (BK), Lemak Kasar (LK), Serat Kasar (SK), Kadar Abu dan BETN. Hasil analisis proksimat selesai pada tanggal 08 April 2019. Hasil analisis proksimat complete feed sapi potong disajikan pada Tabel 2. 
Tabel 2. Hasil analisis proksimat complete feed sapi potong bahan lokal daun kopi

\begin{tabular}{cc}
\hline Nutrisi & Komposisi \\
\hline Kadar air & 12 \\
BK & 88 \\
Protein Kasar & 14,93 \\
Lemak & 3,71 \\
Serat Kasar & 35,99 \\
Kadar Abu & 10,15 \\
BETN & 35,22 \\
\hline
\end{tabular}

Sumber: Lab. badan litbang loka penelitian sapi potong, 2019.

Selanjutnya untuk mengevaluasi kondisi komposisi nutrisi complete feed sapi potong bahan lokal daun kopi, maka dilakukan perbandingan dengan merujuk kepada SNI Mutu Pakan Sapi Potong yang diatur Permentan Nomor 46 tahun 2015. Analisa data komposisi dengan menggunakan diagram batang (bar chart), dapat dilihat pada gambar 1.

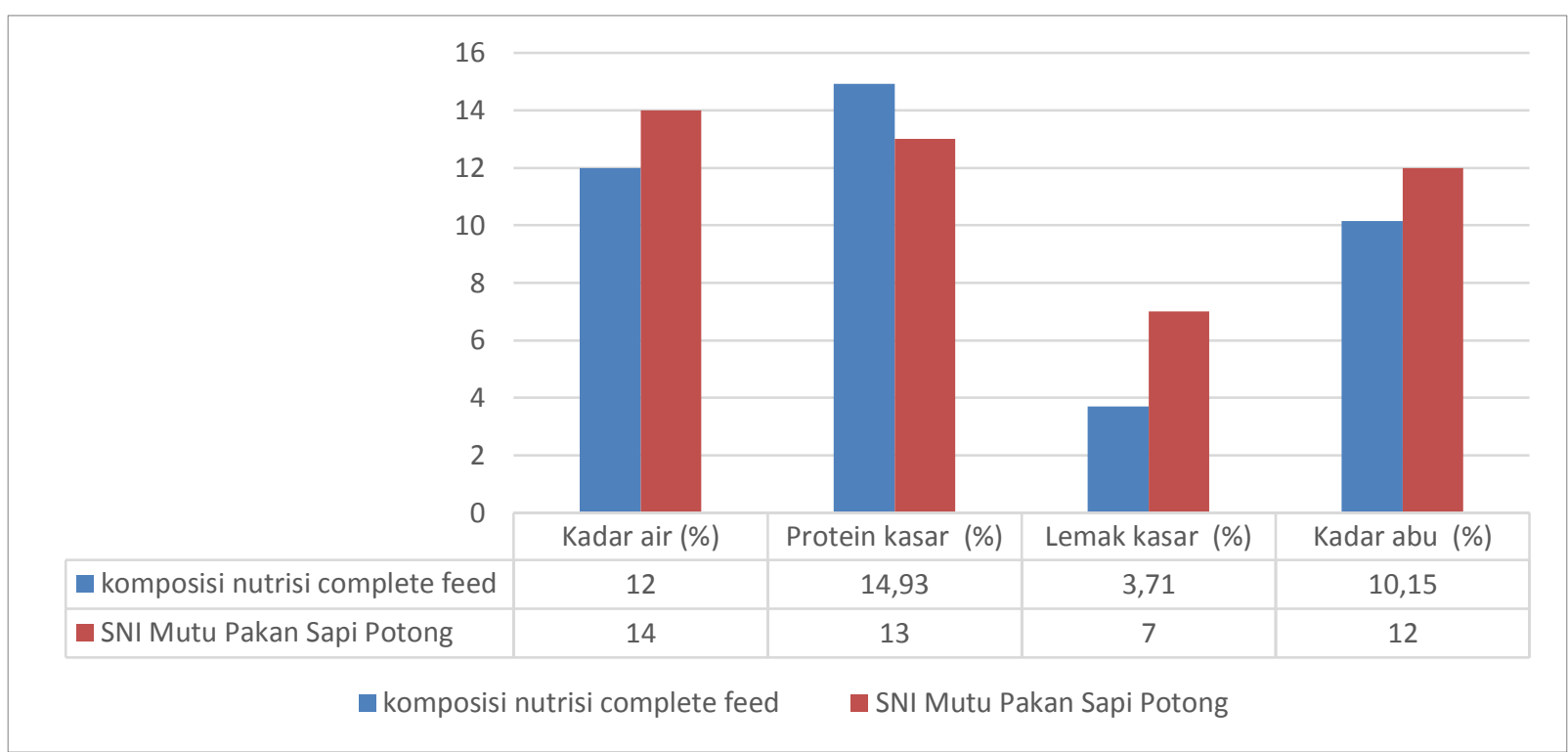

Gambar 1. Perbandingan antara komposisi nutrisi complete feed sapi potong bahan pakan lokal daun kopi dengan SNI Mutu Pakan Sapi Potong.

Memperhatikan diagram batang pada Gambar 1. terlihat ada sedikit perbedaan antara komposisi nutrisi complete feed sapi potong bahan pakan lokal daun kopi dengan SNI Mutu Pakan Sapi Potong, yaitu pada lemak kasar dengan selisih antara 3-4\%.

Kandungan kadar air complete feed adalah 12\%. Artinya kadar air complete feed telah sesuai dengan SNI Mutu Pakan Sapi Potong yang diatur Permentan Nomor 46 tahun 2015 yaitu kadar air maksimal adalah 14\%. Protein Kasar yang terkandung di dalam complete feed yaitu 14,93\%, yang mempunyai arti bahwa complete feed yang disusun telah memenuhi syarat pakan untuk sapi potong penggemukan, indukan dan pejantan. Lemak Kasar yang terkandung di dalam complete feed 3,71\%, yang berarti bahwa complete feed telah memenuhi syarat pakan untuk sapi potong penggemukan, indukan dan pejantan. Kandungan Serat Kasar yang ada di complete feed 35,99\%. Sedangkan kadar abu complete feed 10,15\% dan sudah memenuhi syarat pakan untuk sapi potong penggemukan, induk dan pejantan. Sedangkan kandungan BETN atau Bahan Ekstrak Tanpa Nitrogen yang terkandung 35,22\% yang berarti tingkat kecernaan Serat Kasar complete feed sebesar 35,22\%.

Berdasarkan uraian di atas dapat disimpulkan complete feed untuk sapi potong yang disusun sudah memenuhi syarat SNI Mutu Pakan Nomor 46 Tahun 2015 dan dapat direkomendasikan sebagai pakan complete feed bahan pakan lokal daun kopi untuk peternak di Kab Pasuruan, khususnya peternak yang berada di dataran tinggi.

\section{Uji organoleptik dan palatabilitas complete feed}

Uji organoleptik dilakukan untuk mengevaluasi complete feed berdasarkan karakteristik yang terdiri dari aroma, warna, tekstur dan kontaminasi jamur. Uji organoleptik dilaksanakan di Laboratorium Nutrisi dan Pakan Ternak Kampus Politeknik Pembangunan Pertanian Malang dengan dasar panelis tidak terlatih berjumlah 24 orang dengan syarat seimbang antara laki-laki dan perempuan. Uji organoleptik ini menggunakan kuesioner tertutup. Hasil dari pengujian organoleptik kemudian ditabulasikan. Adapun hasil uji organoleptik fermentasi complete feed dan perbandingan ciri fermentasi complete feed yang berhasil disajikan pada Tabel 3. 
Tabel 3. Analisis hasil uji organoleptik fermentasi complete feed bahan pakan lokal daun kopi

\begin{tabular}{llll} 
No. & \multicolumn{1}{c}{ Kriteria } & \multicolumn{1}{c}{$\begin{array}{c}\text { Ciri-ciri fermentasi complete feed } \\
\text { baik (berhasil) }\end{array}$} & \multicolumn{1}{c}{ Ciri-ciri complete feed hasil uji coba } \\
\hline 1. & Tekstur & Padat & $\begin{array}{l}\text { Padat, tidak menggumpal, tidak berlendir } \\
\text { dan remah }\end{array}$ \\
2. & Warna & Hijau kekuningan & Hijau alami atau hijau kekuningan \\
3. & Aroma & Asam segar & Asam \\
4. & Keberadaan jamur & Tidak ada & Tidak ada
\end{tabular}

Sumber: Pengolahan data primer, 2019.

Gambaran hasil evaluasi fisik pembuatan complete feed bahan lokal daun kopi menunjukkan ciri fermentasi complete feed yang berhasil dan baik. Hal ini ditunjukkan bahwa dilihat dari tekstur yaitu padat, tidak menggumpal, tidak berlendir dan remah, warna hijau alami atau hijau kekuningan, aroma asam dan keberadaan jamur tidak ada. Hal ini sesuai dengan pernyataan Rahmat \& Hariyanto (2017) menyatakan bahwa ciri silase ransum komplit yang berhasil atau berkualitas adalah tekstur padat seperti daun, aroma asam seperti tape berwarna hijau agak kekuningkuningan, tidak ditemukan jamur walaupun penutupan menggunakan silo menggunakan plastik (kelembapan pada silase telah sesuai sehingga proses fermentasi berlangsung secara optimal).

Hasil pembuatan complete feed, kemudian dilakukan uji palatabilitas atau uji kesukaan ternak. Uji palatabilitas dilakukan dengan memberikan complete feed pada 6 ekor sapi potong, di mana 3 ekor merupakan sapi potong milik ketua kelompok dan 3 ekor milik anggota kelompok. Hasil menunjukkan bahwa ke enam sapi tersebut, mau memakan complete feed yang diberikan. Hal ini menandakan bahwa sapi-sapi potong tersebut menyukai pakan complete feed berbahan pakan lokal daun kopi.

\section{Evaluasi aspek ekonomi complete feed sapi potong bahan lokal daun kopi}

Hasil evaluasi aspek ekonomi pembuatan complete feed bahan lokal daun kopi disajikan pada Tabel 4.

Tabel 4. Analisis ekonomis pembuatan fermentasi complete feed bahan lokal daun kopi.

\begin{tabular}{|c|c|c|c|c|}
\hline No & Bahan/Alat & Harga (Rp) & Satuan & Total Harga \\
\hline 1. & Rumput Gajah & 500 & $40 \mathrm{~kg}$ & 20.000 \\
\hline 2. & Daun Kopi & 500 & $20 \mathrm{~kg}$ & 10.000 \\
\hline 3. & Dedak Padi & 2.000 & $10 \mathrm{~kg}$ & 20.000 \\
\hline 4. & Pollard & 3.500 & $28 \mathrm{~kg}$ & 98.000 \\
\hline 5. & Tetes Tebu & 6.000 & 2 liter & 12.000 \\
\hline 6. & EM4 & 23.000 & $30 \mathrm{ml}$ & 690 \\
\hline 7. & Tong & 175.000 & 1 minggu & 1.144 \\
\hline 8. & Peralatan pencacah & 10.000 & 3 jam & 100 \\
\hline 9. & Terpal & 100.000 & 3 jam & 1000 \\
\hline \multicolumn{4}{|c|}{ Hargatotal } & 162.934 \\
\hline \multicolumn{4}{|c|}{ Harga/kg } & $1.629,34$ \\
\hline
\end{tabular}

Sumber: Pengolahan data primer, 2019.

Tabel 4 menunjukkan biaya yang dibutuhkan untuk membuat $100 \mathrm{~kg}$ complete feed Rp. 162.934. Setiap kilogram complete feed membutuhkan biaya sebesar Rp. 1.692,34. Harga produk per satuan kilogram complete feed dari bahan pakan lokal masih lebih murah dibandingkan dengan harga jerami sekalipun padi pada saat musim kemarau tiba.

\section{KESIMPULAN}

Hasil evaluasi untuk penyusunan formulasi dan pembuatan complete feed sapi potong bahan lokal daun kopi, berdasarkan; komposisi nutrisi sudah memenuhi syarat SNI Mutu Pakan Sapi Potong (Permentan Nomor 46 Tahun, 2015), uji organoleptik sudah sesuai dengan ciri-ciri complete feed yang baik (berhasil), uji palatabilitas bahwa sapi menyukai complete feed dengan formulasi yang disusun dan teknik pembuatannya, dan analisa ekonomi bahwa biaya pembuatan complete feed tersebut lebih rendah dari harga jerami padi.

\section{DAFTAR PUSTAKA}

Agustono, B., Lamid, M., Ma'ruf, A., \& Purnama, M. T. E. (2017). Identifikasi limbah pertanian dan perkebunan sebagai bahan pakan inkonvensional di Banyuwangi. Jurnal Medik Veteriner, 1(1), 12-22. http://dx.doi.org/ 10.20473/jmv.vol1.iss1.201

Angkasa, S. (2017). Ramuan pakan ternak. Penebar Swadaya. 
Astuti, U. P., \& Harta, L. (2015). Pemanfaatan daun kopi sebagai pakan ternak ruminansia [Folder]. Balai Pengkajian Teknologi Pertanian (BPTP) Bengkulu. Badan Penelitian dan Pengembangan Pertanian. Kementerian Pertanian.

Baba, S., Muktiani, A., Ako, A., \& Dagong, M. I. A. (2011). Keragaman dan kebutuhan teknologi pakan peternak sapi perah di Kabupaten Enrekang. Media Peternakan, 34(2), 146-154. https://doi.org/10.5398/medpet. 2011.34.2.146

Badan Pusat Statistik [BPS] Jawa Timur. (2019). Badan Pusat Statistik Provinsi Jawa Timur tahun 2019. https://jatim.bps.go.id/subject/54/perkebunan.html\#subjekViewTab3.

Christi, R. F., Rochana, A., \& Hernaman, I. (2018). Kualitas fisik dan palatabilitas konsentrat fermentasi dalam ransum kambing perah peranakan ettawa. Jurnal Ilmu Ternak, 18(2), 121-125. https://doi.org/10.24198 /jit.v18i2.19461

Dewi, A. K. (2018). Persepsi peternak sapi potong tentang strategi bank pakan di Sentra Peternakan Rakyat [SPR] Andini Mulyo Kecamatan Papar Kabupaten Kediri Provinsi Jawa Timur [Tugas Akhir]. Sekolah Tinggi Penyuluhan Pertanian Malang.

Dewi, N.T., Arisoesilaningsih, E., \& Soebarinoto. (2017). Studi etnobiologi pada variasi musiman tumbuhan pakan hijauan di sentra produksi ternak ruminansia. Jurnal Sainsmat, 6(2), 56-62. http://dx.doi.org/ 10.33772/biowallacea.v4i1.3239

Dinas Peternakan Prov Jawa Timur. (2018). Petunjuk pelaksanaan [Juklak] kegiatan inseminasi buatan. Dinas Peternakan Jawa Timur.

Elly, F. H., Waleleng, P. O. V., Lumenta, I. D. R., \& Oroh, F. N. S. ( 2014). Introduksi hijauan makanan ternak sapi di Minahasa Selatan. Pastura, 4(1), 42-45. https://doi.org/10.24843/Pastura.2014.v04.i01.p10

Hidayat, S., \& Mukhlash, I. (2015). Rancang bangun dan implementasi sistem pendukung keputusan berbasis web untuk menentukan formulasi ransum pakan ternak. Jurnal Sains dan Seni, 4(2), 43-48. http://dx.doi.org/10.12962 /j23373520.v4i2.12349

Kuswandi. (2011). Teknologi pemanfaatan pakan lokal untuk menunjang peningkatan produksi ternak ruminansia. Jurnal Pengembangan Inovasi Pertanian, 4(3), 189-204. https://issuu.com/pustaka-bgr/docs/inov043

Permentan R. I. (2015). Peraturan Menteri Pertanian Republik Indonesia Nomor: 46/Permentan/PK.210/8/2015. 2015 tentang Pedoman budidaya sapi potong yang baik. Kementerian Pertanian R.I.

Rahmat. \& Hariyanto, B. (2017). Pakan sapi potong. Penebar Swadaya.

Rianto, E., \& Purbowati, E. (2009). Panduan lengkap sapi potong. Penebar Swadaya.

Septian, F., Kardaya, D., \& Astuti, W. D. (2011). Evaluasi kualitas silase limbah sayuran pasar yang diperkaya dengan berbagai aditif dan bakteri asam laktat. Jurnal Pertanian, 2(2), 117-124. http://dx.doi.org/10.30997/jp.v2i2.576

Thiasari, N., \& Setiyawan, A. I. (2016). Complete feed batang pisang terfermentasi dengan level protein berbeda terhadap kecernaan bahan kering, kencernaan bahan organik dan TDN secara in vitro [Skripsi]. Universitas Tribhuwan Tunggadewi.

Zakariah, M. A. (2016). Teknologi dan fabrikasi pakan. Pustaka Almaida. 